\title{
The emergency of Euphorbia tirucalli as drought feeds for camels in northern Kenya
}

\author{
Anastasia Felisitas Kagunyu ${ }^{1 *}$ and Joseph G. Wanjohi
}

\begin{abstract}
This study took place in Isiolo County in northern Kenya among the Borana community, whose major economic activity is livestock production. The County is characterized by droughts which have increased in frequency and severity. This study sought to investigate the availability of camel drought feeds in the study site, guided by two specific objectives: to establish the existence of supplementary feeds used by the Borana community for camels during the drought periods and to establish the distribution of the supplementary feeds. Data was collected through secondary sources, semi-structured interviews, focus group discussions and direct observation. The study findings indicate that the Borana pastoralists use Euphorbia tirucalli to feed their camels during the drought periods. They also revealed that the plant was sparsely distributed in the study site and most of the feeds were purchased from neighbouring agro-pastoralists at affordable prices. E. tirucalli plays a very important role in saving the lives of camels during drought periods. Therefore, this study recommends that pastoralists in Isiolo County need to be encouraged to plant E. tirucalli in their farms. The Borana pastoralists need to be trained on appropriate methods of harvesting and propagating the plant.
\end{abstract}

Keywords: Euphorbia tirucalli; Camels; Borana; Droughts; Pastoralists

\section{Introduction}

This study was conducted in Isiolo County, northern Kenya. The area lies in arid and semi-arid climatic zones, characterized by low and unreliable rainfall, and drought is a common phenomenon (GoK 2005). The inhabitants of these areas are mainly pastoral communities. Livestock production is their major economic activity; they rear cattle, camels, sheep, goats and donkeys (Kiruthu et al. 2003). However, drought has become very common in Kenya due to climatic changes. According to Kaitho et al. (2006), there has been a change in drought occurrence in Kenya as it used to occur in 10 years, but currently, it is occurring after three years and sometimes after one year. Orindi et al. (2008) report that Kenya pastoral communities have suffered from recent climate extremes.

Recurring droughts and extreme heat are causing livestock keepers to prefer rearing camels rather than other livestock species. Recently, some communities not known to keep camels have started rearing some to supplement

\footnotetext{
* Correspondence: festcy2011@gmail.com

${ }^{1}$ Kenya Agricultural and Livestock Research Organization, P.O. Box 147-60500, Marsabit, Kenya

Full list of author information is available at the end of the article
}

their cattle herds, especially during the dry period (Farm Africa 2002). Kagunyu and Wanjohi (2014) indicated that camel rearing is replacing cattle rearing among the Borana community of northern Kenya. Even some clans among the Borana pastoralists who viewed camel rearing and using camel products as a taboo have started adopting camel rearing. The increased camel production among the Borana, despite the increased severe and prolonged droughts, was the motivation for this study. The study was guided by these objectives: to establish the existence of supplementary feeds used by the Borana community for camels during drought periods and also to establish the distribution of the supplementary feeds.

\section{Study sites}

The study took place in Isiolo County situated in northern Kenya. The study population consisted of Borana men and women household heads. The unit of analysis was the individual household.

\section{它 Springer}

(c) 2015 Kagunyu and Wanjohi. Open Access This article is distributed under the terms of the Creative Commons Attribution 4.0 International License (http://creativecommons.org/licenses/by/4.0/), which permits unrestricted use, distribution, and reproduction in any medium, provided you give appropriate credit to the original author(s) and the source, provide a link to the Creative Commons license, and indicate if changes were made. 


\section{Materials and methods}

\section{Sample size and sampling procedure}

This study applied both random and non-random sampling strategies. In selecting the study site, simple random sampling technique was applied whereby the names of the three Isiolo sub-counties were written on pieces of paper then folded several times and put in a container, which was shaken and the researcher picked one out. Three villages were selected purposively with the help of the local provincial administration who assisted the researcher.

To get a representative sample size, this study used a formula used by Mugenda and Mugenda (2003).

The sample size was determined as follows: $n=z^{2} p q / d^{2}$ where

$n=$ the desired sample size (if the target population is greater than 10,000)

$z=$ the standard normal deviate at the required confidence level

$p=$ the proportion in the target population estimated to have characteristics being measured

$q=1-p$

$d=$ the level of statistical significance set

Since the target population is less than 10,000, the final sample estimate (nf) was calculated as follows:

$$
\begin{aligned}
& \mathrm{nf}=n \\
& 1+n / N
\end{aligned}
$$

where

$\mathrm{nf}=$ the desired sample size (when the population is less than 10,000)

$n=$ the desired sample size (when the population is more than 10,000)

$N=$ the estimate of the population size (Mugenda and Mugenda 2003)

When the population is more than 10,000 households, 384 of them are recommended as the desired sample size (Mugenda and Mugenda 2003: 43). The accessible population in this study was 4,000 households.

Mugenda and Mugenda recommend the formula

$$
\mathrm{nf}=\frac{n}{1+\frac{n}{N}}
$$

to be used to calculate the sample size.

According to the above formula,

$\mathrm{nf}=$ the desired sample size when the population is less than 10,000

$n=$ the desired sample when the population is more than 10,000

$N=$ the estimate of the population size

Using the above formula, the sample size is

$$
\mathrm{nf}=\frac{384}{1+\frac{384}{4,000}}=350
$$

To cater for those households that would decline to participate or dropped out during the process of investigation, the study proposed a sample size of 400 .

A total of 400 households were interviewed. These consisted of 206 men and 194 women. The proportion of men was more than that of women because men were the ones who were readily available.

Systematic sampling was applied to select households for the interview.

The sampling interval was determined by the equation given below.

$$
\text { Sampling interval }=\frac{n}{N}
$$

where

$$
\begin{aligned}
& n=\text { the required sample size } \\
& N=\text { the population size } \\
& n=400 \\
& N=4,000
\end{aligned}
$$

$$
\begin{aligned}
\text { Sampling interval } & =\frac{400}{4,000} \\
& \left.=\frac{1}{10} \text { (i.e. } 1 \text { in } 10\right)
\end{aligned}
$$

Microsoft Excel FUNCTION = RANDBETWEEN $(1,10)$ was used to select a random starting number for the first household to be included in the sample, which happened to be number 8 .

The eighth household was from village 1 since the households were assigned numbers starting from village 1,2 and then 3 .

\section{Data collection methods}

This study was cross-sectional in nature, and both qualitative and quantitative methods were employed. Secondary data was collected through a literature review, while primary data was gathered in household interviews, in focus group discussions and from key informants.

Qualitative data were analysed according to the themes in the research objectives. Quantitative data were analysed using the SPSS software.

\section{Research findings and discussion}

\section{Camel feeds gathered during drought seasons}

This study indicated that in the study area of Isiolo County, an extensive system of camel production is the most common. Due to erratic rains and frequent droughts attributed to climate change, this study revealed that there is a marked fluctuation in feed availability for camels and other livestock in the range lands. This was evidenced by the distance travelled by 
pastoralists in search of green pastures for their livestock. As a result, the Borana pastoralists gather leaves, plants, tubers and pods as emergency feeds for their camels during the drought periods. They used to do this for all livestock species of all ages. More than half $(60 \%)$ of the respondents indicated that they collected anno (Euphorbia tirucalli) for their camels, while $23 \%$ stated that they gathered acacia pods and remains of fruits and vegetables. On the other hand, $10 \%$ of the respondents indicated that they gave crop residues to their camels. The crop residues included stalks of maize and beans from their small-scale farms. Another $7 \%$ said they gave hay and relief feeds to their home-based livestock to sustain them during difficult times (Figure 1).

\section{Depleted forages}

On whether climate change has affected the availability of gathered forages, $88.2 \%$ of the respondents affirmed this, while $11.8 \%$ did not agree. According to those in the affirmative, severe and prolonged droughts have led to the disappearance of valued perennial camel forages such as geddi (Echinochloa haploclada), kumude (Lannea alata), sigirso (Acacia reficiens), hido (Cynodon sp.) and urbu (Acacia tortilis). Acacia pods have become fewer as trees were cut down and used for building and for fuel. The study revealed that the increased frequency of droughts has impacted negatively on the gathering of leaves, seeds, barks and tubers which used to supplement the livestock diet, particularly during times of forage deprivation. Focus group discussants reported that over the years, the availability and quality of pasture has deteriorated. According to them, the encroachment of unwanted plant species such as Acacia drepanolobium and Prosopis juliflora has resulted in a deterioration of the rangelands, since besides reducing the size of the rangelands, their thorns are harmful to humans and livestock.

\section{Camel forages which have appeared}

On whether there were camel forages which had appeared due to climate variability, a majority (63\%) of the respondents stated that there were, while $37 \%$ said that there were none. Those in the majority stated that the following had emerged as a result of climate variability: anno (E. tirucalli); biscuit Mjinga (Prosopis juliflora), commonly known as Mathenge; gurbi (Acalypha sp.); Leucaena leucocephala and Calliandra calothyrsus. Focus group discussants indicated that they had negative attitudes towards the utilization of $P$. juliflora, saying that they had heard that the plant was harmful to livestock and human beings (Figure 1).

\section{E. tirucalli as the most preferred forage for camels}

The Borana pastoral communities have discovered that camels can also feed on anno (E. tirucalli) plants which are used to make live fences. This species is sparsely distributed in Isiolo County since it is only available in a few homesteads and in small quantities. The information gathered from focus group discussions indicated that the plant has become very popular as a camel forage. Camel keepers have been sourcing the forage from the neighbouring County (Meru), and this has promoted peri-urban camel rearing in Isiolo town.

\section{Conclusion and recommendations}

Although E. tirucalli and other shrubs have appeared and others have been introduced, perhaps as a result of climate variability, they were few and in small quantities. Thus, these plants would not be enough as a supplementary feed for the camel populations, as drought has become severe and more frequent than 50 years ago. Therefore, this study recommends that pastoralists in Isiolo County should be encouraged to plant $E$. tirucalli in their farms. The Borana pastoralists need to be trained on appropriate methods of propagating the plant.

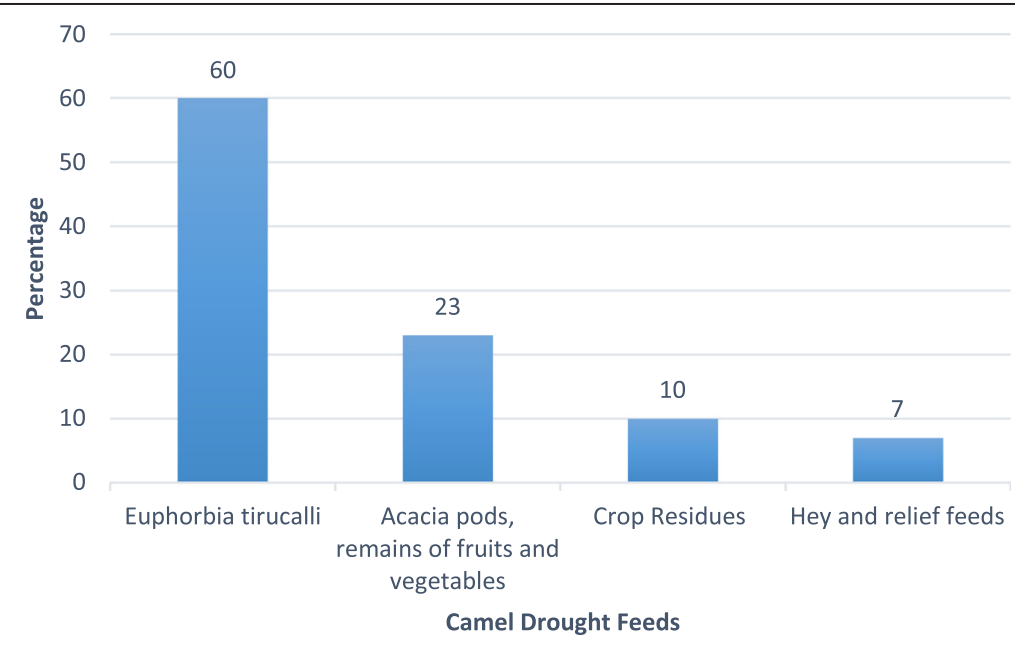

Figure 1 Camel feeds gathered during drought seasons 


\section{Competing interests}

The authors declare that they have no competing interests.

\section{Authors' contributions}

AFK identified the research site, recruited the enumerators and collected and analysed the data. JGW's contribution included data analysis and compiling and editing the work. Both authors read and approved the final manuscript

\section{Authors' information}

AFK is a PhD holder from the University of Nairobi. She is a Senior Research Officer at Kenya Agricultural Research Institute, working as a socio-economist. She has coordinated projects funded by the World Bank and European Union in the arid and semi-arid regions of Kenya. She has carried out policy-related work, research, community development, university lecturing and monitoring and evaluation in local and international organizations based in Kenya.

JGW is a post-graduate student at the Catholic University of Eastern Africa. He works as an instructor in the school for the deaf Technical Institute Karen. He was a project coordinator of SOS based in Nairobi.

\section{Acknowledgements}

Our deepest appreciation and gratitude is extended to the following people for their support in various capacities. We thank the management of Kenya Agricultural and Livestock Research Organization (KALRO) for granting us the time to conduct this study. Our appreciation is also extended to the Borana community of Isiolo for providing us with the information without reservation. We are also grateful to our research assistants who helped us in the data collection.

\section{Author details}

${ }^{1}$ Kenya Agricultural and Livestock Research Organization, P.O. Box 147-60500, Marsabit, Kenya. ${ }^{2}$ Catholic University of Eastern Africa, P.O. Box 62157-00200,

Nairobi, Kenya.

Received: 14 July 2015 Accepted: 13 September 2015

Published online: 30 September 2015

\section{References}

Farm Africa. 2002. Micro-enterprise development. Best practices from FARMAfrica. Nairobi: Farm Africa.

GoK. 2005. Isiolo District Strategic Plan, 2005-2010. Nairobi: Government Printer. Kagunyu, A, and J Wanjohi. 2014. Camel rearing replacing cattle production among the Borana community in Isiolo County of Northern Kenya, as climate variability bites. Pastoralism: Research, Policy and Practice 4: 13. doi:10.1186/s13570-014-0013-6.

Kaitho, R., J. Ndungu, J. Stuth, G. Kariuki and A. Jama 2006. Livestock Information Network and Knowledge Systems (Links) Project. USAID Global Livestock CRSP, Research Brief 06-02 Links. Davis, CA: University of California Press.

Kiruthu, F, J Kapiyo, and M Mama. 2003. The evolving world: A history and government course. Nairobi: Oxford University Press.

Mugenda, O, and A Mugenda. 2003. Research methods: Quantitative and qualitative approaches. Nairobi: African Centre for Technology Studies (ACTS) Press.

Orindi, V, A Nyong, and M Herrero. 2008. Pastoral livelihood adaptation to drought and institutional interventions in Kenya. Nairobi: Human Development Report Office Occasional Paper 2007/2008.

\section{Submit your manuscript to a SpringerOpen ${ }^{\circ}$ journal and benefit from:}

- Convenient online submission

- Rigorous peer review

- Immediate publication on acceptance

- Open access: articles freely available online

- High visibility within the field

- Retaining the copyright to your article 